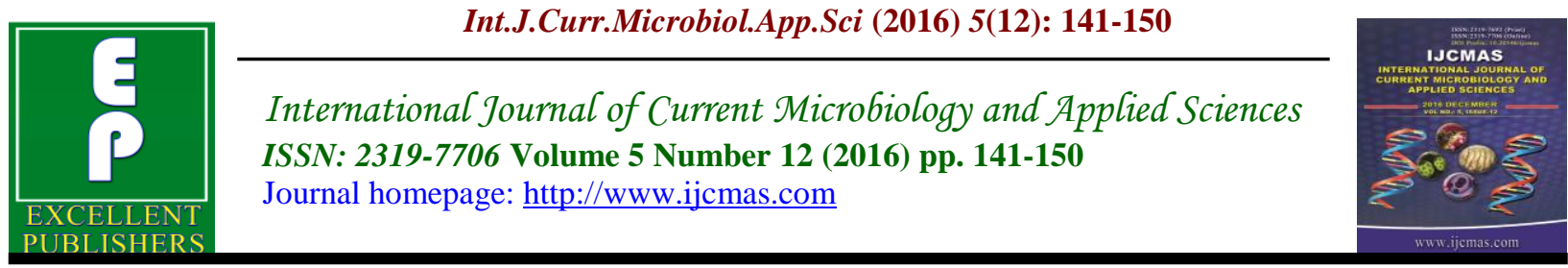

Original Research Article

http://dx.doi.org/10.20546/ijcmas.2016.512.016

\title{
Study of Ligninolytic Bacteria Isolation and Characterization from Kuthrel Agro Field of Bhilai-Durg Region
}

\author{
Sabiha Naz* \\ Department of Biotechnology, Bhilai Mahila Mahavidyalaya, Hospital sector, Bhilai, India \\ *Corresponding author
}

\section{Keywords \\ Lignin, \\ Laccase, \\ Manganese \\ peroxidase, \\ Lignin peroxidase, \\ Bacillus sps., \\ Streptomyces sps.}

\section{Article Info}

Accepted:

08 November 2016

Available Online:

10 December 2016

\section{A B S T R A C T}

After cellulose; lignin is the most abundant renewable carbon source on Earth and very resistant to degradation. In present study isolation and characterization of ligninolytic bacteria were done from Kuthrel agro-fields of Bhilai-Durg regions. Isolation of microbes was done from both mixed and black soil samples by Hungate method. Result shown that four types of bacterial colonies (2-MS, 2-BS) were isolated from agro field. Out of these only 2 types of colonies were shown potential of lignin degradation. The Morphological, biochemical characteristics of the isolates were identified (H)-Bacillus sp. and (h) - Streptomyces sp. with reference to Bergey's Manual of Determinative Bacteriology. These identified isolates Bacillus sps. and Streptomyces sps. were found to have the potential to tolerate high concentrations of kraft lignin and produced all three main ligninolytic enzymes (lignin peroxidase, manganese peroxidase, and laccase). These enzymes were quantified in 2 bacterial strains evaluated at $\mathrm{pH} 7.4$ ( $\mathrm{LiP}=$ veratryl alcoholguaiacol; $\mathrm{MnP}=$ lactate-guaiacol-Mn+2; laccase = ABTS-catalase). From these, two strains (Bacillus species and Streptomyces species) showed the most activity for Li peroxidase strains Bacillus species and Streptomyces species also had the greater activity for Mn peroxidase and Laccase. This result concluded that both kinds of strains were able to degrade lignin substrate and have specific advantages for the depolymerization of the modified lignin residues typically encountered in waste streams from the pulping or $2^{\text {nd }}$ generation biofuel/biobased chemicals industry.

\section{Introduction}

Environmental issues and concerns aimed at reducing the ambient pollution have boosted the search for "clean Technologies" to be used in the production of commodities of importance to chemical, energy and food industries. This practice makes use of alternative materials, requires less energy, and diminishes pollutants in industrial effluents, as well as being more economically advantageous due to its reduced costs. Considering this scenario, the use of residues from agroindustrial, forestry and urban sources in bioprocesses has aroused the interest of the scientific community lately. The utilization of such materials as substrates for microbial 
cultivation intended to produce cellular proteins, organic acids, mushrooms, biologically important secondary metabolites, enzymes, prebiotic oligosaccharides, and as sources of fermentable sugars in the second generation ethanol production have been reported (Sánchez, 2009).

Agroindustrial wastes are valuable sources of lignocellulosic materials. The lignocellulose is the main structural constituent of plants and represents the primary source of renewable organic matter on earth. It can be found at the cellular wall, and is composed of cellulose, hemicellulose and lignin, plus organic acids, salts and minerals (Pandey et al., 2000; Hamelinck et al., 2005). Several agroindustrial wastes are commonly used for this purpose, such as sugarcane bagasse, wheat bran, corn cob and straw, rice straw and husk, soy bran, barley and coffee husk (Sanchéz, 2009). Therefore, such residues are superior substrates for the growth of filamentous fungi, which produce cellulolytic, hemicellulolytic and ligninolytic enzymes by solid state fermentation (SSF). Filamentous fungi are the most distinguished producers of enzymes involved in the degradation of lignocellulosic material, and the search for new strains displaying high potential of enzyme production is of great biotechnological importance. Notably, the microbial enzymes can be the products themselves as well as tools in these bioprocesses. Microbial cellulases, xylanases and ligninases are enzymes with potential application in several biotechnology processes (Bocchini et al., 2003; Kumar et al, 2004; Maicas and Mateo, 2005; Graminha et al., 2008; Hebeish et al., 2009).

Present research works focus on the isolation and characterization of ligninolytic bacteria from Kuthrel agro-fields. Aim of the Isolation and characterization of ligninolytic bacteria to identify their ligininolytic enzyme potential and further use of these enzymes potential for the degradation of lignocellulosic materials.

\section{Materials and Methods}

\section{Sources of Isolates}

The bacteria were isolated from 2 types of soil samples black and mixed soil of agro fields. The agro fields of Kuthrel of BhilaiDurg were selected for isolation of Ligninolytic bacterial colony.

\section{Isolation and Selection of Ligninolytic Bacteria}

Microbes from both mixed and black soil samples were grown in solid media by Hungate method (Ogimoto and Imai, 1981). In warm condition, media was divided into 3 tubes. Each selective substrate then dissolved, and then poured $15 \mathrm{ml}$ each into Petri disc. Microbes sources soil sample were serially diluted with $10^{-5}$ dilution then $(100 \mu \mathrm{l})$ soil sample was inoculated for 7-14 days. The growing colonies then were counted and identified. The lignin degrader bacteria was selected qualitatively based on the diffusion zone diameter that formed around colony (Subbarao, 1993: Samingan, 1998: Martani, 2003). Each isolate was inoculated by spot method on nutrient agar that contains 1\% tannic acid (Subbarao, 1993). Diffusion and clear zone were measured after 7 days of anaerobic incubation. Diffusion zone with colony size was used to determine the selected isolates.

\section{Identification of Selected Microbes}

The pure cultures of lignin degrading microbes were selected and subjected to 
various morphological studies, various types of differential staining (Gram's and endospore) and biochemical characterization tests (catalase test, starch hydrolysis, Indole, MR-VP, simmon's citrate agar, fermentation, $\mathrm{H}_{2} \mathrm{~S}$ production, nitrate reduction, urease, casein hydrolysis, gelatin hydrolysis) to determine the identity of the bacterial isolates with reference to Bergey's Manual of Determinative Bacteriology (Buchanan and Gibbon, 1974).

\section{Lignin Degradation Study in Pure Culture}

After screening and identification of lignin degrading bacterial strains of Kuthrel of Bhilai-Durg argofield were used for the check the quantitative estimation of lignin degradation capability by Chandara et al., (2007) and For the measurement of lignin degradation, $1 \mathrm{ml}$ of samples were centrifuged at $15000 \mathrm{rpm}$ for $5 \mathrm{~min}$. Supernatant $(250 \mu \mathrm{l})$ was diluted by adding $2.5 \mathrm{ml}$ phosphate buffer (pH 7.6) and absorbance measured at $280 \mathrm{~nm}$ for lignin degradation on a UV-visible spectrophotometer (Perkin Elmer Lambda EZ201 UV/VIS Spectrometer) Lara et al., (2003) methods.

\section{Enzyme Assays}

Presence of lignin degrading enzymes activity in lignin degrading bacteria were measured by followed Laccase activity by (Machado and Matheus, 2006) method Manganese peroxidase (MnP), by (Glenn and coworkers, 1986) method and Lignin peroxidase (LiP) activity by (Tie et al., 1988) method.

\section{Results and Discussion}

In the present study, the isolation and characterization of naturally ligninolytic bacterial flora from Kuthrel agro-fields of Bhilai-Durg were done. The bacteria were isolated from 2 types of soil samples black and mixed soil of agro fields.

\section{Isolated Bacterial Colonies from Kuthrel Agro Fields}

Bacterial colonies were isolated from both mixed and black soil samples of Kuthrel agrofield and grown in solid media by Hungate method. Four types of bacterial colonies (2-MS, 2-BS) were isolated and used to check the activity of ligninolytic capability Kuthrel agro field (Table- 1).

\section{Qualitative Selection of Ligninolytic Bacterial Colonies}

All ten isolated bacterial colonies of Kuthrel were subjected for qualitative selection of the lignin degrading bacteria. Selection was based on the diffusion zone diameter that formed around colony. Each isolate was inoculated by spot method on nutrient agar that contains $1 \%$ tannic acid. Diffusion and clear zone were measured after 7 days of anaerobic incubation. In Kuthrel agro field out of 4 colonies only 2 types of colonies were shown diffusion zone with colony size was determined the potential of lignin degradation (Table-2).

\section{Identification of Selected Ligninolytic Bacterial Colonies}

In present studies Kuthrel agro field 2 bacterial colonies were shown potential of lignin degradation. The Morphological characteristics of obtained microbes from the soil samples on Nutrient Agar (NA) and Eosin Methylene blue (EMB) agar was shown in (Table-3). The gram's reaction and endspores staining reaction for the characterization of isolates obtained was also shown on (Table-3). The Biochemical 
characteristics of the isolates obtained from this agro-field soil samples was shown in (Table-4). The isolated bacteria species were identified with reference to Bergey's Manual of Determinative Bacteriology (Buchanan and Gibbons, 1974). These identified isolates included (H)-Bacillus species and (h) - Streptomyces species (Table 4).

\section{Detection of ligninolytic capability of isolated Bacteria}

The isolated lignin degrading bacteria $(\mathrm{H})$ Bacillus sp. and (h) - Streptomyces sp. from Kuthrel (Durg Balod Road) were found the potential ligninolytic capability which was assessed by growth on kraft- lignin, utilization of lignin-associated aromatic monomers and degradation of lignin from 0 6 days. Bacillus species exhibited best growth and degradation of lignin fractions where as Streptomyces sp. showed comparatively less degradation of lignin fractions from 0 to 6 days of incubation (Table- 5).

\section{Enzyme Assays}

The isolated bacterial strains $\mathrm{H}-$ Bacillus species, h- Streptomyces species were found the potential to degraded kraft lignin and produced all three main ligninolytic enzymes (lignin peroxidase, manganese peroxidase, and laccase); these strains may therefore be useful in the degradation of lignin. These enzymes were quantified in bacterial extracts evaluated at $\mathrm{pH} 7.6(\mathrm{LiP}=$ veratryl alcohol-guaiacol; $\mathrm{MnP}=$ lactateguaiacol-Mn+2; laccase $=$ ABTS-catalase) . From these, two strains (Bacillus species and Streptomyces species) showed the maximum activity for $\mathrm{Li}$ peroxidase also had the greater activity for $\mathrm{Mn}$ peroxidase and Laccase shown in (Table-6).
Borgmeyer and Crawford (1985) have identified a quantitatively major intermediate of lignin degradation by Streptomyces viridosporus. Results indicated that differing mechanisms of lignin metabolism may exist in these two Streptomyces sp. strains. $S$. viridosporus. Godden et al., (1992) were grown six biodegradative actinomycete strains on a dimeric model lignin compound of the p-aryl ether type. Although only two strains, Thermomonosporu mesophila and Streptomyces badius, utilized the compound as a carbon and energy source and produced substantial amounts of monomeric products. Extracellular peroxidase and catalase activity were detected in all of the strains. Bandounas et al., (2011) were identified the organisms based on 16S rRNA gene sequencing and phenotypic characterization, as Pandoraea norimbergensis LD001, Pseudomonas sp LD002 and Bacillus sp LD003. The ligninolytic capability of each of these isolates was assessed by growth on high-molecular weight and low-molecular weight lignin fractions, utilization of ligninassociated aromatic monomers and degradation of ligninolytic indicator dyes. Rodriguez et al., (2011) research was characterized and identified bacterial strains with ligninolytic activity. 150 different strains were isolated out of these 80 strains showed ligninolytic activity. Their enzymatic extracts were obtained from bacterial strains and qualitative colorimetric assays were carried out to evaluate ligninolytic activity. Morphological, biochemical, and DNA analysis indicate that at least two of the best ligninolytic strains are Bacillus spp.

Rahman et al., (2013) were isolated three aerobic lignin-degrading bacterial strains from palm oil plantation soils. The bacterial isolates were screened using a selective nutrient medium. The newly isolated 
bacterial strains $\mathrm{SHC} 1, \mathrm{SHC} 2$, and $\mathrm{SHC} 3$ as Bacillus sp., Ochrobactrum sp., and Leucobacter sp., were found to have the potential to tolerate high concentrations of kraft lignin and produced all three main ligninolytic enzymes (lignin peroxidase, manganese).

Naz, (2014) were characterized and identified the naturally ligninolytic bacterial flora from Bharda Khar agro-fields of Bhilai-Durg. Investigation found that from the both soil samples of Bharda Khar agrofield Pseudomonas aerugionosa and Baccillus sp., 2 types of ligninolytic bacterial colonies were isolated and given positive results for various ligninolytic enzymes i.e. (Laccase, Magnese Peroxidase and Lignin Peroxidase). This result concluded that both kinds of strains were able to degrade lignin substrate which was second abundant and waste material in the world. Naz et al., (2015) studied the characterization and identification of naturally ligninolytic bacterial flora from the Dhamdha agro-fields of Bhilai-Durg region and 74 strains from both black and mixed soil sample were isolated out of these 2 strains showed ligninolytic activity. Their enzymatic extracts were obtained from bacterial strains and qualitative colorimetric assays were carried out positive results for various ligninolytic enzymes (Laccase, Magnese Peroxidase and Lignin Peroxidase). Morphological and biochemical analysis indicate that ligninolytic strains are Baccillus sp. was able to degrade lignin substrate.

Previous studied were shown that Bacillus sp. and Streptomyces sp. have lignin degrading capability by produce all three main ligninolytic enzymes. Present study shown similarity with the previous research work. The bacterial isolates in this study appear to have an alternative type of ligninolytic system. This result concluded that both kinds of strains were able to degrade lignin substrate and have specific advantages for the depolymerization of the modified lignin residues typically encountered in waste streams from the pulping or $2^{\text {nd }}$ generation biofuel/biobased chemicals industry.

Table.1 Bacterial colonies isolated from Kuthrel agro-field

\begin{tabular}{|c|c|c|}
\hline Sample Site & \multicolumn{2}{|c|}{ Kuthrel Agro-Field } \\
\hline Types of Soils & Mixed Soil & Black Soil \\
\hline Types of Colonies & 2 & 2 \\
\hline No. of Colonies & g-64 & G-25 \\
& h-256 & H-128 \\
\hline
\end{tabular}

Table.2 Ligninolytic colonies selected from isolated bacterial colonies of Kuthrel agro-field

\begin{tabular}{|c|c|c|}
\hline Sample Site & \multicolumn{2}{|c|}{ Kuthrel Agro-Field } \\
\hline Types of Soils & Mixed Soil & Mixed Soil \\
\hline Types of Colonies & 1 & 1 \\
\hline $\begin{array}{c}\text { Selected ligninolytic colonies and their } \\
\text { Zone Diameters (mm) }\end{array}$ & h-15 & H-30 \\
\hline
\end{tabular}


Table.3 Shown morphological characteristic of isolated microbes from Kuthrel agro-field soil samples

\begin{tabular}{|c|l|c|}
\hline Isolates & \multicolumn{1}{|c|}{ Morphological Characteristics } & Organisms \\
\hline $\mathrm{h}$ & $\begin{array}{l}\text { Non-spore forming and non-motile, Gram positive cocci, } \\
\text { circular, low convex with entire margin, smooth, medium, } \\
\text { opaque, golden yellow colony on Nutrient Agar, }\end{array}$ & Streptomyces sp. \\
\hline $\mathrm{H}$ & $\begin{array}{l}\text { Spore forming, Gram positive rods, creamy white colony on } \\
\text { Nutrient Agar entire margin }\end{array}$ & Bacillus sp. \\
\hline
\end{tabular}

Table.4 Shown biochemical test for identification of isolated bacteria from soil samples of Kuthrel agro-field

\begin{tabular}{|c|c|c|c|}
\hline \multirow[t]{2}{*}{ S. No. } & \multirow[t]{2}{*}{ Biochemical test } & \multicolumn{2}{|c|}{ Kuthrel Agro-Field } \\
\hline & & $\mathrm{H}$ & $\mathrm{H}$ \\
\hline 1. & Motility test & + & - \\
\hline 2. & Catalase test & + & + \\
\hline 3. & $6.5 \% \mathrm{NaCl}$ & - & - \\
\hline 4. & Glucose fermentation test & $\mathrm{A} / \mathrm{G}$ & A \\
\hline 5. & Lactose fermentation & A & - \\
\hline 6. & Sucrose fermentation & $\mathrm{A} / \mathrm{G}$ & A \\
\hline 7. & Starch Hydrolysis & - & - \\
\hline 8. & Indole test & - & - \\
\hline 9. & MR Test & - & - \\
\hline 10. & VP Test & + & + \\
\hline 11. & Citrate test & - & - \\
\hline 12. & Urease test & - & + \\
\hline 13. & Gelatin Hydrolysis & + & - \\
\hline 14. & $\mathrm{H}_{2} \mathrm{~S}$ Production & + & ND \\
\hline 15. & Nitrate Utilization & + & - \\
\hline 16. & Lipid Hydrolysis & + & - \\
\hline 17. & Oxidase Test & + & - \\
\hline
\end{tabular}

Note: ND-Not Determined, A -Acid, A/G-Acid/Gas, + =Positive, - =Negative, $(+)=$ Late Positive 
Fig.1 Shown bacterial colonies isolated from Kuthrel agro-field

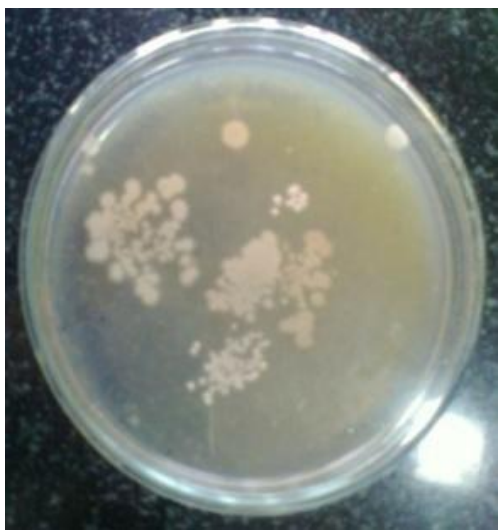

Fig.2 Shown biochemicals tests for characterization of isolated ligninolytic bacterial colonies from five different agro fields

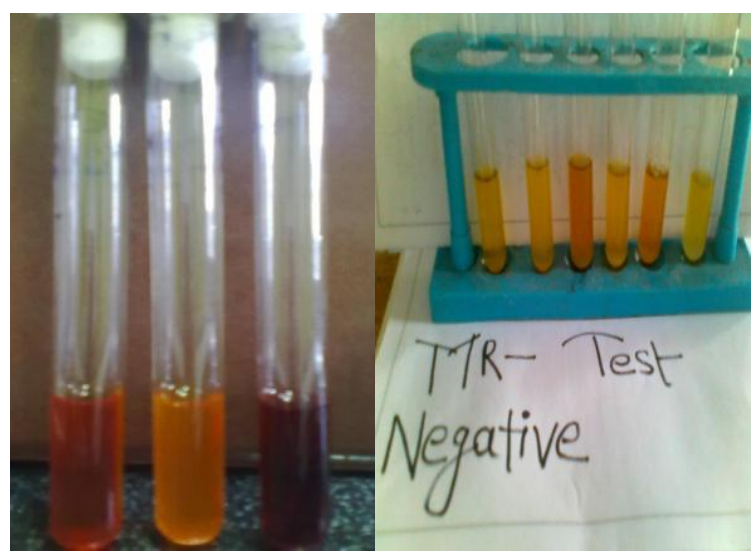

MR tests(-ve) for both strains

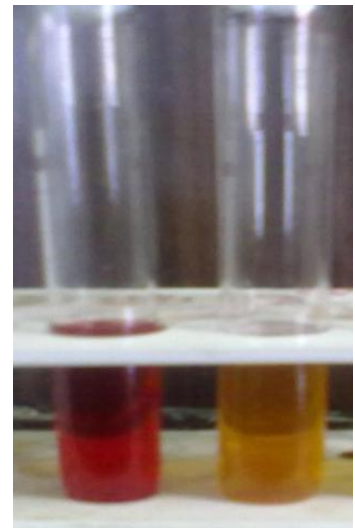

Glucose tests (+ve)

for both strains

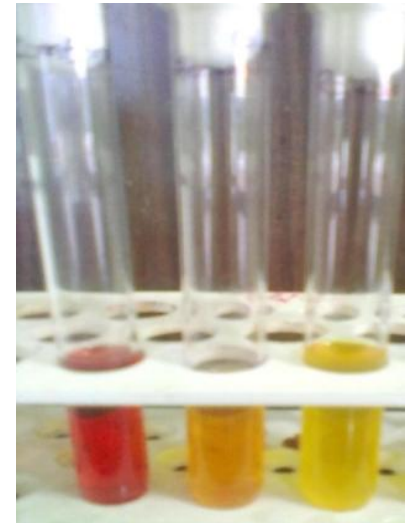

Lactose tests (+ve)

for $\mathrm{H}$ and(-ve) for h strain

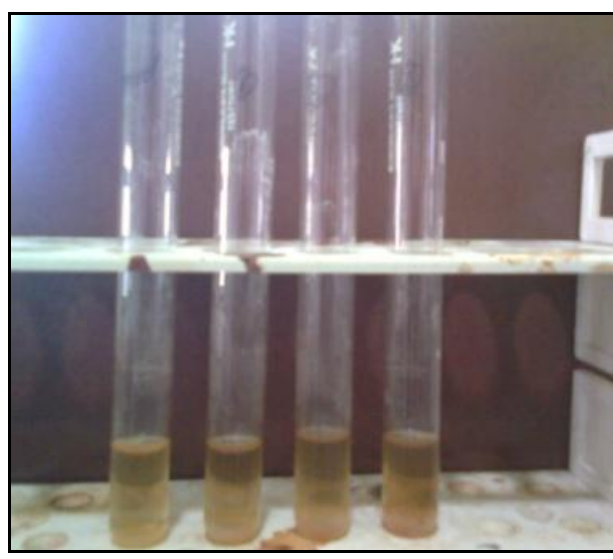

VP tests (-ve) for both strains

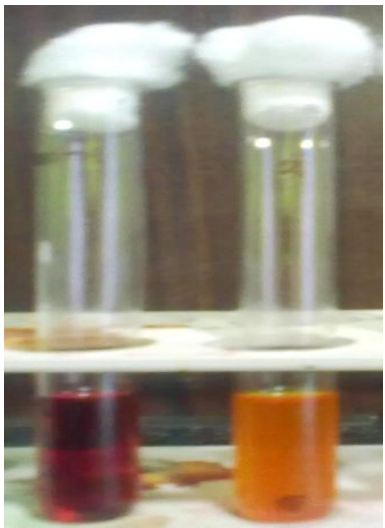

Sucrose tests (+ve)

for both strains 


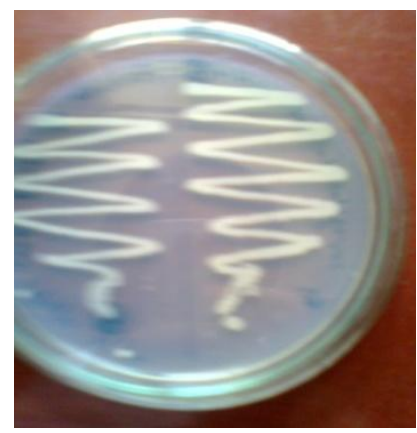

$6.5 \% \mathrm{NaCl}$ growth tests (-ve) for both strains

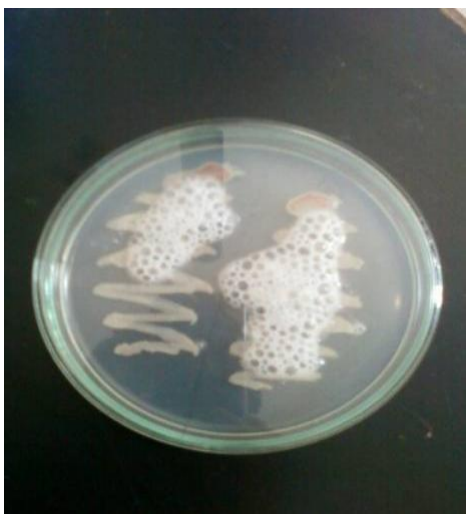

Catalase (+ve) test for $\mathrm{H}, \mathrm{h}$ strain

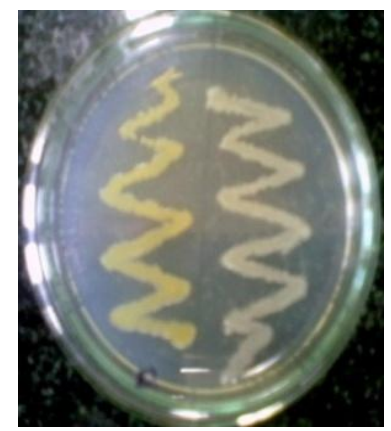

Starch hydrolysis tests (-ve) for both strains

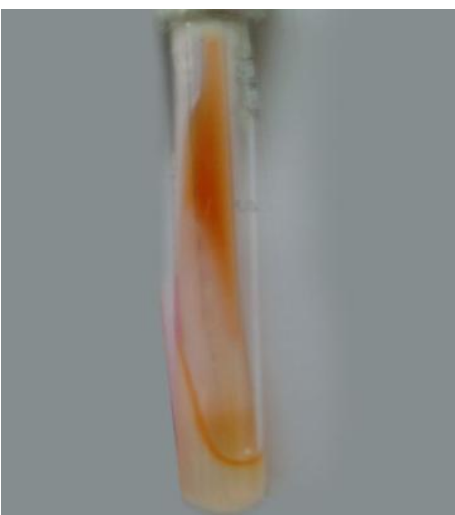

Urease (+ve) test for $h$ strain

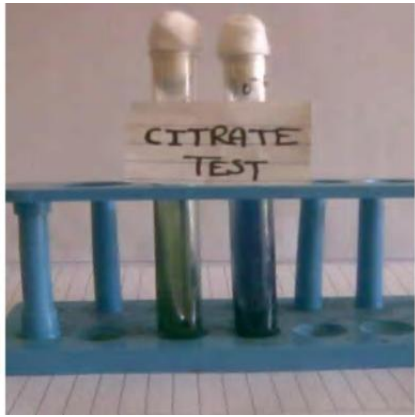

Citrate test (-ve) for $\mathrm{H}, \mathrm{h}$, strain

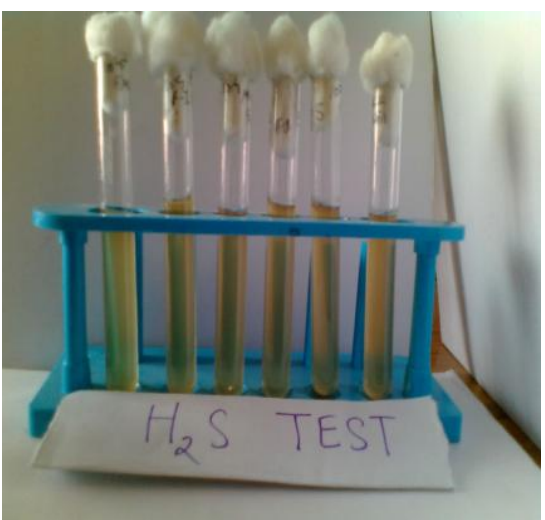

$\mathrm{H}_{2} \mathrm{~S}$ test (+ve) for $\mathrm{h}$ and (-ve) for $\mathrm{H}$ strain

Table.5 Lignin residue during the incubation time 0-144 h (0-6 day) bacterial strains at pH 7.6

\begin{tabular}{|c|c|c|c|c|c|}
\hline Bacterial & \multicolumn{5}{|c|}{ Residue of lignin (mg /L) at incubation times (h) } \\
\hline Strains & 0 & 24 & 48 & 96 & $144 \mathrm{~h}$ \\
\hline Bacillus sp. & 1000 & 589.12 & 497.20 & 413.26 & 383.32 \\
\hline Streptomyces sp. & 1000 & 879.45 & 818.06 & 754.95 & 399.75 \\
\hline
\end{tabular}

Table.6 Shown lignin degradation enzymes study of isolated bacterial strains from Kuthrel agro-field

\begin{tabular}{|c|c|c|c|c|}
\hline \multirow{2}{*}{$\begin{array}{c}\text { S. } \\
\text { No. }\end{array}$} & \multirow{2}{*}{$\begin{array}{c}\text { Lignin Degrading Bacterial } \\
\text { colonies }\end{array}$} & \multicolumn{3}{|c|}{ Presence of Lignin Degrading Enzymes } \\
\cline { 3 - 5 } & & Laccase & $\begin{array}{c}\text { Manganese } \\
\text { peroxidase (MnP) }\end{array}$ & $\begin{array}{c}\text { Lignin peroxidase } \\
\text { (LiP) }\end{array}$ \\
\hline 1. & Bacillus sp. & + & ++ & +++ \\
\hline 2. & Streptomyces sp. & + & ++ & +++ \\
\hline
\end{tabular}

In conclusion, in the present study, the characterization and identification of naturally ligninolytic bacteria from the
Kuthrel agro-fields of Bhilai-Durg, using an industrial lignin residue from the Kraft process. The bacteria were isolated from 2 
types of soil samples black and mixed soil sample of agro fields. In present investigation found that from the both soil samples of Kuthrel agro- Bacillus sp. and Streptomyces sp. 2 types of ligninolytic bacterial colonies were isolated. Both type strains given positive results for various ligninolytic enzymes i.e. (Laccase, Magnese Peroxidase and Lignin Peroxidase). This result concluded that both kinds of strains were able to degrade lignin substrate which was second abundant and waste material in the world. It is also concluded that to expand on the range of products which can be obtained from lignocellulosic biomass, the lignin component should be utilized as feedstock for value- added chemicals such as substituted aromatics, instead of being incinerated for heat and energy. Enzymes could provide an effective means for lignin depolymerization into products of interest. They may also have specific advantages for the depolymerization of the modified lignin residues typically encountered in waste streams from the pulping or 2nd generation biofuel/biobased chemicals industry.

\section{Acknowledgement}

This paper work is part of research of Minor Research Work that funding by Under Grand Commission for Research and Community Services of Bhilai Mahila Mahavidyalaya, Hospital Sector, Bhilai. I am highly grateful for the opportunity permitted by the head of the institute of Bhilai Mahila Mahavidyalaya, Bhilai for carrying out my work here. It is a pride for me to express my gratitude to my Honorable Principal Dr. (Mrs.) Zehra Hasan Madam.

\section{References}

Bandounas, L., Wierckx, N.J. P., Winde, J.H. de and Ruijssenaars, H.J. 2011. Isolation and characterization of novel bacterial strains exhibiting ligninolytic potential. BMC Biotechnol., 11: 94-102.

Bocchini, D.A., Damiano, V.B., Gomes, E. and Da Silva, R. 2003. Effect of Bacillus circulans D1 Thermostable Xylanase on Biobleaching of Eucalyptus Kraft Pulp. Appl. Biochem. Biotechnol., 105(1-3): 393-401.

Borgmeyer, J.R. and Crawford, D.L. 1985. Production and Characterization of Polymeric Lignin Degradation Intermediates from Two Different Streptomyces spp. Appl. Environ. Microbiol., 49(2): 273-278.

Buchanan, R.E. and Gibbons, N.E. 1974. Bergey's Manual of Determinative Bacteriology."8th eds. 290340. Williams and Wilk ins, Baltimore, Maryland.

Chandra, R., Raj, A., Purohit, H.J. and Kapley, A. 2007. Characterisation and optimization of three potential aerobic bacterial strains for Kraft lignin degradation from pulp paper waste. Chemosphere, 67: 839-846.

Glenn, J.K., Akileswarean, L., Gold, M.H. 1986. Mn(II) oxidation is the principle function of the extracellular Mnperoxidase from Phanerochaetes

chrysosporium. Arch. Biochem. Biophys., 251(6): 88-696.

Godden, B., Ball, A.S., Helvenstein, P., Mccarthy, A.J. and Penninckx, M.J. 2008. Towards elucidation of the lignin degradation pathway in actinomycetes. J. General Microbiol., 138: 2441-2448.

Graminha, E.B.N., Gonçalves, A.Z.L., Pirota, R.D.P.B., Balsalobre, M.A.A., Da Silva, R., Gomes, E. 2008. Enzyme Production by Solid-State Fermentation: Application to Animal Nutrition. Animal Feed Sci. Technol., 144: 1- 22.

Hamelinck, C.N., Hooijdonk, G.V., Faaij, A.P.C. 2005. Ethanol from lignocellulosic biomass: technoeconomic performance in short-, middle-and long-term. Biomass and Bioenergy, 28: 384-410.

Hebeish, A., Hashem, M., Shaker, N., 
Ramadan, M., El-Sadek, B., Hady, M.A. 2009. Effect of Post- and PreCrosslinking of Cotton Fabrics on the Efficiency of Biofinishing with Cellulase Enzyme. Carbohydrate Polymer, 78: 953-960.

Kumar, K.B., Balakrishnan, H., Rele, M.V. 2004. Compatibility of Alkaline Xylanases from an Alkaliphilic Bacillus NCL (87-6-10) With Commercial Detergents and Proteases. J. Industrial Microbiol. Biotechnol., 31: 83-87.

Lara, M.A., Malaver-Rodriguez, A.J., Rojas, O.J., Holmquist, O., Gonzalez, A.M., Bullon, J., Penaloza, N. and Araujo, E. 2003. Black liquor lignin biodegradation by Trametes elegans. Int. Biodeterior. Biodegrad., 52: 67-175.

Machado, K.M.G., Matheus, D.R. 2006. Biodegradation of remazol brilhant blue $\mathrm{R}$ by ligninolytic enzymatic complex produced by Pleurotus ostreatus. Braz. J. Microbiol., 37: 468-473.

Maicas, S. and Mateo, J.J. 2005. Hydrolysis of Terpenyl Glycosides in Grape Juice and other Fruit Juices: A Review. Appl. Microbiol. Biotechnol., 67(3): 322 335.

Martani, E.N. Haedar and Margino, S. 2003. Isolation and characterization of lignin degrading bacteria from several natural substrates. Gama Stains, (2): 32 -35.

Naz, S. 2014. Isolation and characterization of ligninolytic bacteria from Bharda Khar agro field of Bhilai-Durg. Online Int. Interdisciplinary Res. J., \{Bi-Monthly\}, IV, Special Issue 156-166.

Naz, S., Devtare, S., Satapathy, S., Gupta, S. 2015. Study of ligninolytic bacteria isolation and characterization from
Dhamdha agro field of Bhilai-Durg region. Int. J. Res. Engi. Technol., 4(2): 258-262.

Ogimoto, K. and Imai, S. 1981. Atlas of Rumen Microbiology. Japan Scientific Societies Press, Tokyo.

Pandey, A., Soccol, C.R., Nigam, P., and Soccol, V.T. 2000. Biotechnological potential of agro-industrial residues. I. Sugarcane bagasse, Biores. Technol., 74: 69- 80.

Rahman, N.H. A., Rahman, N.A.A., Suraini A.A. and Hassan, M.A. 2013. Production of Ligninolytic Enzymes by Newly Isolated Bacteria from Palm Oil Plantation Soils. Bio Res., 8(4): 120128.

Rodriguez, A.A., Leyva, M.J., Portugal, V.O., Navarro, J.R., Moreno, C.R. 2011. Isolation, characterization, and identification of ligninolytic bacterial strains. AACC International poster meeting.

Samingan. 1998. Biodegradation of Acacia mangium Wild offal by lignocellulolytic fungi. Thesis, Graduate School, University of Gadjah Mada, Yogyakarta.

Sanchez, C. 2009. "Lignocellulosic residues: biodegradation and bioconversion by fungi," Biotechnol Adv., 27(2): 185-194.

Subbarao, N.S. 1993. Biofertilizers in Agriculture and Forestry. 3rd ed. International Science Publisher, New York.

Tien M., Kirk K.T., Wood K., Kellogg S.T. 1988. Lignin peroxidase of Phanerochaetes chrysosporium. Methods Enzymol., 161(part B): 238249.

\section{How to cite this article:}

Sabiha Naz. 2016. Study of Ligninolytic Bacteria Isolation and Characterization from Kuthrel Agro Field of Bhilai-Durg Region. Int.J.Curr.Microbiol.App.Sci. 5(12): 141-150. doi: http://dx.doi.org/10.20546/ijcmas.2016.512.016 